\title{
IMPLEMENTASI PROSES BELAJAR PAI DI SMP ALKHAIRAAT TOLIBA
}

\author{
Nurmaya Medopa \\ Program Studi Pendidikan Bahasa Arab, FAI, Universitas Alkhairaat \\ nurmayamedopa@gmail.com
}

\begin{abstract}
ABSTRAK
Penelitian ini meliputi implementasi, implikasi, faktor pendukung, penghambat implementasi belajar Pendidikan Agama Islam di SMP Alkhairaat Toliba. Penelitian menggunakan pendekatan metode kualitatif berdasarkan penelitian lapangan, data penelitian dihimpun melalui observasi, wawancara, dokumentasi, analisis, reduksi, penyajian, verifikasi data. Hasil penelitian ditemukan bahwa: Implementasi proses belajar Pendidikan Agama Islam di SMP Alkhairaat Toliba meliputi cakupan kurikulum, proses dan evaluasi, konsep KTSP, menciptakan culture religious sebagai implementasi dari proses belajar. Implikasi proses belajar Pendidikan Agama Islam dalam meningkatkan pemahaman keagamaan peserta didik di SMP Alkhairaat Desa Toliba memberikan pengaruh positif pada peningkatan pemahaman peserta didik di atas standar ketuntasan minimum proses belajar Pendidikan Agama Islam. Faktor pendukung; kemampuan guru, penyediaan alat peraga/media pembelajaran, dukungan kepala madrasah dan stekholder. Faktor penghambatnya yaitu: Ketersediaan waktu belajar Pendidikan Agama Islam yang terbatas, kesulitan menghadapi karakter peserta didik.
\end{abstract}

Kata Kunci : Implementasi, Proses, Belajar, Pendidikan, Agama, Islam.

\begin{abstract}
This research includes implementation, implications, supporting factors, obstacles to the implementation of Islamic Religious Education learning at Alkhairaat Toliba Middle School. The research used a qualitative approach based on field research, the research data were collected through observation, interviews, documentation, analysis, reduction, presentation, and data levers. The results of the study found that: The implementation process of learning Islamic religious education at SMP Alkhairaat Toliba includes curriculum evaluation, evaluation process, the concept of KTSP, creating a religious culture as an implementation of the learning process. The implication of the learning process of Islamic Religious Education in increasing the religious understanding of students at Alkhairaat Junior High School in Toliba Village has a positive effect on increasing students' understanding above the standard of completeness of the Islamic Religious Education learning process. Supporting factors; the ability of teachers, provision of teaching aids / learning media, support for madrasah principals and staff. The inhibiting factors are: a picture of limited time to study Islamic Religious Education, difficulties in dealing with the character of students.
\end{abstract}

Keywords : Implementation, Process, Learning, Education, Religion, Islam

\section{PENDAHULUAN}

Pendidikan keagamaan dalam dunia pendidikan formal merupakan salah satu bahan kajian dalam kurikulum semua jenis pendidikan dan jenjang pendidikan yang pembelajarannya dibimbing oleh guru PAI. Pembelajaran PAI sebagai bidang studi dalam kurikulum pendidikan. Sebagai bidang studi pelajaran, pendidikan agama 
diberikan di sekolah maupun madrasah sebagai wahana untuk mempersiapkan pribadi atau individu menjadi peserta didik yang memahami dan mengamalkan nilainilai ajaran agama Islam. pendidikan memiliki peranan yang sangat penting dan tak dapat dipisahkan, terdapat faktor yang mempengaruhinya sebagaimana pada uraian berikut: UU 20/2003, pasal 3, UU 20/2003, pasal 36 dan UU 20/2003, pasal $30 / 2$.

Berdasarkan uraian di atas pendidikan Agama Islam merupakan bidang studi yang diberikan kepada peserta didik yang syarat dengan muatan nilai. Dalam konteks pendidikan di Indonesia yang memeluk agama Islam seharusnya Pendidikan Agama Islam mendasari pendidikan-pendidikan lain, serta menjadi inti pembelajaran bagi peserta didik.

Menurut Zakiyah Daradjat yang diuraikan oleh Abdul Majid: "Pendidikan Agama Islam adalah suatu usaha untuk membina dan mengasuh peserta didik agar senantiasa dapat memahami ajaran Islam secara menyeluruh dan menghayati tujuan, yang pada akhirnya dapat mengamalkan Islam sebagai pandangan hidup". (Abdul Majid, 2012).

Masih terdapat kekurangan dari proses belajar Pendidikan Agama Islam di sekolah, misalnya: aspek teologi, terdapat kecenderungan tertujuh pada pemahaman tertentu. Akhlakulkarimah tentang sopan santun, masih kurang diimplementasikan. Ibadah ditransfer melalui rutinitas namun belum mengarah pada proses terbentuknya pribadi berakhlakul karimah. Memahami Al-Qur'an belum mencakup keseluruhan makna, masih tertujuh pada memahami teks, namun belum mengarah memahami makna sesungguhnya.

Pelaksanaan pendidikan agama Islam dilembaga pendidikan yang diselenggarakan di sekolah mempunyai kedudukan yang sangat penting dalam membimbing pengetahuan keagamaan peserta didik. Kemampuan dan pengetahuan keagamaan yang dipelajari, diharapkan dapat menjadi pegangan saat bertindak untuk melakukan suatu perbuatan terpuji.
Implementasi proses belajar PAI diharapkan memberikan out put yang baik. Implementasi bukan sekedar aktivitas, tetapi suatu kegiatan yang terencana dan untuk mencapai tujuan kegiatan. Implementasi memiliki makna melaksanakan, proses transfer pembelajaran pengetahuan. Beberapa penelitian terdahulu yang memeiliki keterkaiatan pada penelitian yang dilakukan pada penelitian ini, dapat penulis uraikan sebagai berikut:

Penelitian yang dilakukan oleh Barikatul Hikmah, UIN Sunan Ampel Surabaya di tahun 2011 dengan judul "Implementasi pembelajaran pendidikan agama islam dengan pendekatan gaya belajar visual, auditorial, kinestetik dalam meningkatkan daya ingat peserta didik kelas VII Adan B Di SMP Antartika Surabaya dari hasil penelitian tersebut ditemukan bahwa: Implementasi pembelajaran Pendidikan Agama Islam di SMP Antartika Surabaya lebih banyak menggunakan dua metode, yakni metode ceramah tujuh puluh tiga persen dan metode demonstrasi empat puluh tiga persen; (2) Daya ingat peserta didik tentang implementasi belajar PAI yang menggunakan metode ceramah dan demonstrasi adalah kadang-kadang mengingat (ceramah, tujuh puluh tiga persen yakni cukup baik), (demonstrasi, lima puluh persen yakni kurang baik). Sedangkan kebosanan menerima materi dengan dua metode tersebut tidak ada kebosanan (ceramah, tujuh puluh tiga persen yakni cukup baik), (demonstrasi, lima puluh tujuh persen yakni cukup baik); (3) Respon peserta didik terhadap implementasi belajar PAI dengan pendekatan gaya belajar visual, auditorial, kinestetik dalam meningkatkan daya ingat adalah sangat baik. Yakni mencapai tujuh puluh persen yang menyatakan setuju dengan penerapan gaya belajar tersebut dalam satu pembelajaran, terutama pembelajaran Pendidikan Agama Islam. Maka hasil prosentase ini termasuk dalam kategori cukup baik.

Hasil penelitian menunjukkan faktor komunikator memberikan pengaruh terhadap sikap peserta didik melalui belajar PAI, sedangkan faktor pesan terbukti 
memberikan pengaruh hanya disaat peserta didik mampu memahami pesan. Artinya pesan yang disampaikan harus dapat dipastikann mampu difahami secara baik oleh peserta didik. Demikian juga faktor komunikator sebagai faktor luar dilihat dari tingkat perhatian, tingkat pemahaman dan tingkat penerimaan terbukti memberikan pengaruh positif dalam meningkatkan terhadap belajar PAI. Hal ini terlihat dari tingginya antusiasme peserta didik dalam menerima pelajaran pendidikan agama Islam, sehingga memudahkan penerimaan pesan yang disampaikan guru, dan berdampak pada sikap peserta didik melalui belajar PAI.

Penelitian Sasmiyah dengan judul Peningkatan Pemahaman Pembelajaran Pendidikan Agama Islam Materi Shalat Melalui Media Gambar Kelas III SD Negeri Sukorejo I Mertoyudan Magelang Tahun 2012. Sekolah Tinggi Agama Islam Negeri Salatiga 2012, Hasil penelitian tersebut adalah minat belajar peserta didik terhadap mempelajari ibadah shalat di SD Negeri Sukorejo I Mertoyudan setelah menggunakan media gambar mengalami peningkatan. Pada pra siklus ke siklus I minat peserta didik meningkat sebanyak sembilan puluh dua koma enam persen. Setelah menggunakan media gambar prestasi belajar peserta didik SD Negeri Sukorejo I Mertoyudan mengalami peningkatan dari siklus I menjadi siklus II sebanyak sembilan puluh delapan koma tiga persen. Peserta didik yang belum mencapai nilai KKM pada pra siklus sebanyak 13 peserta didik dan yang mencapai nilai KKM sebanyak 18 peserta didik. Pada siklusi terdapat sejumlah peserta didik yang belum memenuhi nilai KKM 6 orang dan yang sudah mencapai nilai KKM sebanyak 25 orang. Pada siklus II peserta didik yang belum mencapai nilai KKM sebanyak 3 peserta didik dan mencapai nilai KKM sebanyak 29 peserta didik.

Berdasarkan pada telaah pustaka yang dilakukan penulis menyimpulkan bahwa penelitian yang penulis akan teliti pada penelitian ini memiliki perbedaan terhadap berbagai penelitian sebelumnya yang secara khusus diarahkan pada jangkauan implementasi proses belajar PAI dalam meningkatkan pemahaman keagamaan peserta didik di SMP Alkhairaat Desa Toliba Kecamatan Tojo Barat Kabupaten Tojo. Perbedaan tersebut terletak pada bagian-bagian berikut:

1. Variabel penelitian

2. Sasaran penelitian

3. Tempat dan waktu penelitian

4. Metode penelitian

5. Hasil penelitian

"proses belajar terkait dengan bagaimana pembelajaran dikuasai peserta didik atau bagaimana membuat peserta didik dapat belajar dengan mudah dan terdorong oleh kemampuannya sendiri". (Muhaimin, 2002). Pembelajaran adalah belajar, belajar adalah sebagai sebagai hasil dari pengamatan dan latihan. (Hasan Shadily, t.t). Yang dimaksudkan pembelajaran di sini adalah kegiatan merubah tingkah laku yang diupayakan oleh dua belah pihak yaitu antara pendidik dan peserta didik. (Ramayulis, 2006).

\section{METODE PENELITIAN}

Guna mendapatkan hasil maksimal dalam penelitian, peneliti menggunakan metode kualitatif deskriptif, yaitu penelitian yang bertujuan mendeskripsikan data-data atau hasil penemuan yang ditemukan oleh peneliti di lapangan, agar data tersebut disajikan secara akurat. Penelitian kualitatif pada prinsipnya merupakan upaya untuk menemukan teori yang dapat menunjang hasil penelitian dan hal itu dilakukan melalui analisis induktif. Dengan pendekatan tersebut data dikumpulkan kemudian dianalisis, diabstraksikan. (Lexy J. Moelong, 2000).

Adapun lokasi penelitiannya adalah Sekolah Menengah Pertama Alkhairaat Toliba Kecamatan Tojo Barat Kabupaten Tojo. Penelitian yang bersifat kualitatif menuntut akan keaktifan langsung peneliti, maka keberadaan peneliti dilokasi mutlak sebagai instrumen. Peran peneliti di lapangan sebagai partisipasi penuh dan aktif karena peneliti yang langsung mengamati dan mencari informasi melalui informan atau nara sumber. 
Sebagaimana yang diketahui, data di ditentukan berdasarkan klasifikasi data. Sumber data dapat digolongkan ke dalam data primer dan data sekunder. "Data primer adalah data yang didapat melalui sumber pertama, baik individu atau perorangan, seperti hasil wawancara atau hasil pengisian kuesioner yang bisa dilakukan oleh pendidik". (Husen Umar, 2001).

Data sekunder, yaitu sumber data tambahan yang menurut peneliti menunjang data pokok. Sumber sekunder adalah sumber informasi yang tidak secara langsung diperoleh dari orang atau lembaga yang mempunyai kewenangan terhadap informasi. Informasi tersebut diklasifikasikan melalui tiga jenis, yaitu: (1) sumber dokumenter; (2) sumber kepustakaan; (3) sumber lapangan. (Mahmud, 2011).

Aspek lain yang diperlukan ialah observasi. Observasi merupakan hasil mengamati yang berisi catatan terstruktur terhadap gejala yang tampak pada objek penelitian. (Winarno Surakhman, 1987). Observasi pada penelitian ini cara untuk mendapatkan data melalui pengamatan langsung secara sistematis tentang fenomena yang diteliti di lokasi penelitian, yaitu SMP Alkhairaat Toliba Kecamatan Tojo Barat Kabupaten Tojo, dalam penelitian ini peneliti menggunakan observasi partisipasi dimana penulis turut mengambil bagian pada pelaksanaan pembelajaran dalam mengamati, mendampingi dan terlibat dalam membantu proses pembelajaran yang terjadi.

Wawancara adalah percakapan dengan maksud tertentu, percakapan yang dilakukan antara dua belah pihak, yaitu antara pewawancara dan pihak yang diwawancarai yang akan memberikan jawaban yang diharapkan oleh pewawancara. (Lexy J. Moelong, 2000).

\section{HASIL DAN PEMBAHASAN}

\section{A. Implementasi Proses Belajar PAI di SMP Alkhairaat Toliba Kecamatan Tojo Barat Kabupaten Tojo}

Pendidikan Agama Islam bertujuan untuk memberikan pelajaran lebih dalam kepada peserta didik. Pelajaran PAI bertujuan mempelajari berbagai aspek yang diharapkan akan membawa peserta didik menjadi pribadi yang agamais dan berbudi pekerti luhur. Sesuai dengan cita-cita pendidikan nasional yaitu mendidik generasi yang memiliki kecerdasan, keterampilan, penuh tanggungjawab, memiliki kesehatan mental, maupun rohani.

Pada Implementasi proses belajar PAI di SMP Alkhairaat Toliba yang menjadi fokus pada penelitian ini meliputi aspek kurikulum, proses dan evaluasi proses belajar PAI, adapun hasil penelitian yang penulis temukan pada ketiga aspek tersebut dapat diuraikan sebagai berikut:

1. Kurikulum

Kurikulum pada Sekolah Menengah Pertama Alkhairaat Toliba merupakan program yang berisi perencaanaan dan tata cara sesuai tujuan, isi dan bahan pembelajaran yang mengacu pada pedoman diselenggarakannya proses belajar pendidikan nasional.

\section{Proses}

Pendidikan harus dilakukan sesuai rencana yang bersandar pada proses belajar yang terarah guna mendapatkan hasil yang sesuai rumusan, tujuan pendidikan, sehingga kemampuan peserta didik, dari segi pengetahuan, keterampilan dan spiritual.

Pembelajaran adalah proses edukasi berdasarkan materi belajar dari guru kepada siswa. Kegiatan proses belajar bergantung melalui komponen yang melingkupinya.

Dari sekian banyak komponen tersebut maka yang paling utama adalah adanya peserta didik, tenaga pendidik, media pembelajaran, materi pembelajaran serta adanya rencana pembelajaran. Proses belajar PAI di SMP Alkahairaat Toliba disajikan untuk memfasilitasi perkembangan kemampuan berfikir peserta didik melalui penggunaan metode pembelajaran yang mendorong peserta didik untuk aktif bertanya, mengemukakan pendapat, atau menguji cobakan suatu materi, melakukan dialog dan diskusi. Sehingga proses belajar PAI mengandung makna serta fungsi dalam kehidupan mereka. Dalam aspek proses belajar PAI pada penelitian mengkaji penggunaan 
metode, media/alat dan pendekatan pembelajaran.

\section{Evaluasi}

Evaluasi merupakan bagian yang tidak dapat dipisahkan dari proses pembelajaran, tujuan evaluasi adalah menggali informasi pengetahuan belajar peserta didik sesuai bahan belajar, mengembangkan minat belajar peserta didik berdasarkan materi pembelajaran.

Selain itu, program evaluasi memiliki tujuan guna mendapatkan informasi peserta didik yang memiliki kemampuan memahami materi belajar dengan baik dan benar. Proses evaluasi tidak hanya untuk peserta didik saja, namun ditujukan kepada pendidik, agar evaluasi ini berjalan secara maksimal.

\section{B. Implikasi Proses Belajar PAI dalam Meningkatkan Pemahaman Keagamaan Peserta Didik di SMP Alkhairaat Toliba Kecamatan Tojo Barat Kabupaten Tojo \\ Berhasilnya proses belajar, diukur} melalui kemampuan menumbuhkan, mendampingi, mengarahkan, menggali kecerdasan kognitif, afektif dan psikomotor peserta didik. Tugas pokok dari satuan pendidikan memaksimalkan ketuntasan minimal belajar atas dasar pertimbangan kemampuan belajar peserta didik, meliputi kemampuan sumber daya pendukung pada proses belajar. Lembaga pendidikan ditugaskan agar mampu meningkatkan kriteria ketuntasan belajar berkesinambungan dan kontinyu untuk mencapai kriteria ketuntasan ideal sesuai dengan tuntutan undang-undang.

Implikasi proses belajar PAI dalam meningkatkan pemahaman keagamaan peserta didik di SMP Alkhairaat Toliba, Seorang peserta didik dikatakan memahami apabila dapat menjelaskan atau memberi uraian lebih tentang aspek yang telah dipelajari serta kemampuan memberikan atau mensinergikan pemahaman dengan permasalahan-permasalahan yang ada di sekitarnya kemudian mengimplementasikan aspek pemahaman tersebut dalam kehidupan kesehariannya. Pemahaman merupakan batasan atau pencapaian kompetensi mempelajari materi pelajaran yang diberikan kepada peserta didik.
Sebagaimana yang diketahui bahwa peserta didik menerima pembelajaran dengan kemampuan yang berbeda-beda.

Dari hasil belajar tersebut dapat diketahui, bahwa kemampuan peserta didik dapat menerima pembelajaran dengan pemahaman yang utuh dan ada pula yang tidak mampu menerima secara sempurna. Pemahaman merupakan hasil belajar dapat pula dikatakan prestasi belajar, adapun prestasi belajar dapat penulis pahami sebagai hasil yang diperoleh dari sesuatu yang telah diusahakan, berdasarkan nilai belajar yang telah berproses. Apabila dianalisis dalam pendidikan prestasi merupakan hasil pemahaman yang didapat, kemampuan menguasai pembelajaran. Sehingga prestasi dapat diukur dengan nilai yang diperoleh melauli pengadaan test maupun evaluasi dalam belajar.

Peningkatan pemahaman keagamaan merupakan salah satu tujuan belajar PAI, manfaat belajar, pedoman dan arah kegiatan belajar sampai hasil yang diharapkan. Tujuan dari kegiatan pembelajaran tidak akan pernah tercapai selama komponenkomponen lainnya tidak dimaksimalkan. Proses belajar PAI di SMP Alkhairaat Toliba sebagai suatu kegiatan pembinaan dan penanaman nilai religiusitas tentunya mempunyai pengaruh dalam keberhasilan dan kemampuan peserta didik memahami materi yang telah diajarkan. Dalam pembelajaran diperlukan suasana yang kondusif yang mendukung sebab tinggi dan rendahnya pemahaman peserta didik dipengaruhi oleh kreatifitas guru dalam pembelajaran.

Melalui berbagai upaya: penyusunan kurikulum, pembelajaran dan evaluasi proses belajar PAI yang diterapkan di SMP Alkhairaat Toliba maka peningkatan pemahaman peserta didik dapat mengalami peningkatan yang signifikan yang memperoleh nilai rata-rata di atas ketuntasan minimum sebagai target nilai dalam belajar, bila dibandingkan dengan pembelajaran Pendidikan Agama Islam pada tahun sebelumnya sebelumnya, untuk lebih jelasnya hasil prestasi. 


\section{Faktor Pendukung dan Penghambat Proses Belajar PAI di SMP Alkhairaat Toliba Kecamatan Tojo Barat Kabupaten Tojo}

Setiap usaha pastilah adanya penghambat maupun pendukung, di mana keduanya sangatlah berpengaruh besar pada tingkat keberhasilan suatu tujuan, demikian pula dengan proses belajar PAI di SMP Alkhairaat Toliba dalam pelaksanaannya juga memiliki faktor, baik bersifat penghambat ataupun bersifat pendukung:

Faktor pendukung implementasi proses belajar PAI dalam meningkatkan pemahaman keagamaan peserta didik di SMP Alkhairaat Toliba adalah sebagai berikut:

1. Kemampuan guru

Sebagaimana yang diketahui guru memiliki kemampuan kompetensi melakukan kegiatan pembelajaran, diantara kemampuan tersebut ialah menguasai isi, tujuan belajar PAI.

2. Terpenuhinya penyediaan alat peraga/media pembelajaran

Dalam kegiatan belajar mengajar maka alat atau media sangat diperlukan agar dapat menunjang tercapainya tujuan pendidikan. Alat atau media pembelajaran di SMP Alkhairaat Toliba cukup memadai dalam menunjang pembelajaran sehingga segala aktivitas mengajar dapat dibantu dengan media tersebut.

3. Dukungan kepala madrasah dan stakeholder yang terkait

Kepercayaan masyarakat terhadap SMP Alkhairaat Toliba menjadi semakin meningkat, hal ini disebabkan tanggung jawab kepala madrasah secara komprehensif terbatas pada tugas internal sekolah saja tetapi juga tugas diluar sekolah yaitu berhubungan dan berinteraksi dengan masyarakat dan pihak orang tua peserta didik. Kepala sekolah sangat aktif dalam membangun hubungan berupa informasi dan permintaan saran dari pihak lain dalam pengembangan pendidikan di SMP Alkhairaat Toliba termasuk pada pengembangan Pendidikan Agama Islam.

Adapun faktor penghambat implementasi proses belajar PAI dalam meningkatkan pemahaman keagamaan peserta didik di SMP Alkhairaat Toliba adalah sebagai berikut:

1. Ketersediaan waktu belajar PAI yang terbatas.

Waktu tersedia sangat terbatas dengan materi yang cukup tinggi (padat). Oleh karenanya, sangat sulit memberikan pemahaman PAI di sekolah yang waktunya terbatas. Untuk mensiasati kekurangan waktu guru PAI SMP Alkhairaat Toliba dengan memberikan tugas tagihan. Yaitu para peserta didik diberi tugas untuk dikerjakan di rumah dan selanjutnya ditagih jawabannya di kelas.

2. Peserta didik memiliki karakter berbeda.

Karakter yang berbeda dari peserta didik, masing-masing individu memiliki pengetahuan yang berbeda, kesulitan menentukan materi yang cocok dengan kejiwaan dan jenjang pendidikan peserta didik, kesulitan dalam menyesuaikan materi melalui penyajian metode yang bervariasi.

Uraian diatas memberikan pemahaman bahwa guru atau pendidik sebaiknya melakukan inovasi tidak hanya mampu merencanakan

PBM, mempersiapkan bahan pengajaran, merencanakan media dan sumber pembelajaran, serta waktu dan teknik penilaian terhadap prestasi siswa, namun juga harus mampu melaksanakan semua itu sesuai dengan program yang telah dibuat.

Tabel 1. Keadaan Peserta Didik SMP Alkhairaat Toliba

\begin{tabular}{|c|c|c|c|c|c|}
\hline \multirow{2}{*}{ No } & \multirow{2}{*}{ Kelas } & \multicolumn{2}{|c|}{ Jumlah } & \multirow{2}{*}{ Jumlah } & \multirow{2}{*}{ Ket } \\
\hline & & laki-laki & Perempuan & & \\
\hline 1 & VII & 23 & 28 & 51 & Aktif \\
\hline 2 & VIII & 15 & 10 & 25 & Aktif \\
\hline \multirow[t]{2}{*}{3} & IX & 12 & 13 & 25 & Aktif \\
\hline & Jumlah & 60 & 48 & 101 & \\
\hline
\end{tabular}


Data tersebut merupakan jumlah peserta didik secara keseluruhan yang terdaftar di SMP Alkhairaat Toliba, hal ini membuktikan bahwa lembaga pendidikan tersebut masih cukup mendapat apresiasi dan dukungan yang besar dari masyarakat setempat. Hal ini dilihat dari jumlah peserta didik yang terus mengalami peningkatan pada tiap penerimaan peserta didk ditiap tahunnya, dari hal tersebut membuktikan bahwa apresiasi masyarakat dalam mempercayakan lembaga pendidikan SMP Alkhairaat Toliba sebagai wadah pendidikan terhadap putra putri mereka cukup tinggi.

Tabel 2. Cakupan Kurikulum SMP Alkhairaat Toliba

\begin{tabular}{|c|c|c|}
\hline No & $\begin{array}{l}\text { Kelompok Mata } \\
\text { Pelajaran }\end{array}$ & Cakupan \\
\hline 1. & $\begin{array}{l}\text { Agama dan Akhlak } \\
\text { Mulia }\end{array}$ & $\begin{array}{l}\text { Bidang studi PAI dan akhlak memiliki tujuan agar peserta } \\
\text { didik dapat meningkatkan keimanan, ketakwaan kepada Allah } \\
\text { SWT. }\end{array}$ \\
\hline 2. & $\begin{array}{l}\text { Kewarganegaraan } \\
\text { dan Kepribadian }\end{array}$ & $\begin{array}{l}\text { Bidang studi PKN bermaksud meningkatkan kesadaran, } \\
\text { wawasan, kewajiban, hak peserta didik sebagai warga Negara } \\
\text { yang baik. }\end{array}$ \\
\hline 3. & $\begin{array}{l}\text { Ilmu Pengetahuan } \\
\text { dan Teknologi }\end{array}$ & $\begin{array}{l}\text { Bidang studi IP\&T pada Sekolah Menengah Pertama } \\
\text { Alkhairaat Toliba dimaksudkan untuk mengenal, menyikapi, } \\
\text { dan mengapresiasi ilmu pengetahuan dan teknologi. }\end{array}$ \\
\hline 4. & Estetika & $\begin{array}{l}\text { Bidang studi estetika untuk meningkatkan sensitivitas, } \\
\text { ekspresi, apresiasi, keindahan dan harmoni. }\end{array}$ \\
\hline 5. & $\begin{array}{l}\text { Jasmani, Olahraga } \\
\text { dan Kesehatan }\end{array}$ & $\begin{array}{l}\text { Bidang studi jasmani, olahraga dan kesehatan pada SMP } \\
\text { Alkhairaat Toliba dimaksudkan untuk meningkatkan potensi } \\
\text { fisik, sportivitas, hidup sehat. }\end{array}$ \\
\hline
\end{tabular}

Kurikulum, proses belajar PAI yang dirancang di SMP Alkhairaat Toliba menghantarkan peserta didik mampu memahami penguasaan ilmu pengetahuan tentang PAI mengamalkan ajaran Islam. Sikap pribadi, ahlak yang baik, memiliki pengetahuan tentang ajaran Islam dan dipelajari melalui PAI. Dengan demikian, karakter bangsa Indonesia didasarkan kepada nilai-nilai ke-Tuhanan Yang Maha Esa, yang merupakan inti dari sila-sila lain yang ada dalam Pancasila. dan menyeimbangkan antara Iman, Islam, dan Ihsan.

\section{KESIMPULAN}

Berdasarkan hasil temuan dalam penelitian yang penulis lakukan, "Implementasi proses belajar PAI dalam meningkatkan pemahaman keagamaan peserta didik di SMP Alkhairaat Toliba Kecamatan Tojo Barat Kabupaten Tojo", maka penulis dapat merumuskan jawaban permasalahan yang diangkat pada penelitian ini dengan beberapa kesimpulan sebagai berikut:

1. Implementasi proses belajar PAI di SMP Alkhairaat Toliba Kecamatan Tojo Barat Kabupaten Tojo meliputi aspek kurikulum, proses dan evaluasi. 1) Kurikulum yang diterapkan pada Sekolah tersebut adalah KTSP yang berupa dokumen yang berisi rencana, tujuan, isi dan bahan pembelajaran serta cara yang digunakan melalui tutor pembelajaran langsung dikelas, menciptakan culture religious sebagai implementasi dari pembelajaran. 2) Proses belajar PAI di SMP Alkhairaat Toliba, mengadopsi konsep pembelajaran bermakna yakni menjadikan pengetahuan yang dipelajari relevan dengan kebutuhan peserta didik, membuka peluang yang baik, melakukan pengamatan, mengumpulkan data, menganalisis, menemukan dan menyimpulkan, konsep tersebut relevan dengan konsep belajar bermakna David Ausabel. 
2. Implikasi proses belajar PAI dalam meningkatkan pemahaman keagamaan peserta didik di SMP Alkhairaat Desa Toliba sangat berpengaruh positif pada peningkatan pemahaman pembelajaran PAI diukur dari prestasi belajar peserta didik di atas standar ketuntasan minimum pembelajaran Pendidikan Agama Islam.

3. Faktor-faktor pendukung proses belajar PAI dalam meningkatkan pemahaman keagamaan peserta didik di SMP Alkhairaat Toliba adalah Kemampuan guru, penyediaan alat peraga/media pembelajaran dan dukungan kepala madrasah dan stekholder yang terkait. Adapun faktor penghambat implementasi proses belajar PAI yaitu: Ketersediaan waktu belajar PAI yang terbatas dan kesulitan dalam menghadapi karakter peserta didik yang beragam.

\section{DAFTAR PUSTAKA}

Mahmud, (2011). Metode Penelitian Pendidikan (Cet. X; Bandung: Pustaka Setia,

Majid, Abdul. (2012). Belajar dan Pembelajaran Pendidikan Agama Islam. Bandung: Remaja Rosdakarya,

Muhaimin. (2002). Paradigma Pendidikan Islam: Upaya Mengefektifkan PAI di Sekolah Bandung: Remaja Rosdakarya.

Moelong, Lexy J. (2000). Metodologi Penelitian Kualitatif, (Cet. XII; Bandung: Remaja Rosdakarya.

Ramayulis. (2006). Ilmu Pendidikan Islam Jakarta: Kalam Mulia.
Shadily, Hasan.
(t.t) Ensiklopedi Indonesia Jakarta: Ictiar Baru-Van Hoeve dan Elsevier Publishing Projects.

Surakhman, Winarno. (1987). Research, Pengantar Metodologi Ilmiah (Ed, VI; Bandung : Tarsito.

Umar, Husen. (2001). Metode Penelitian Untuk Skripsi dan Terisi Bisnis, Cet. I; Jakarta: PT. Raja Grapindo Persada. 